\title{
Efektivitas Ekstrak Biji Srikaya (Annona squamosa L.) sebagai Bahan Pembersih Gigi Tiruan terhadap Daya Hambat Pertumbuhan Streptococcus mutans pada Basis Akrilik Heat Cured
}

\section{The Effectiveness of Srikaya (Annona squamosa L.) Seed Extract as Denture Cleanser Agent to Growth Inhibition of Streptococcus mutans in Denture Acrylic Base}

\author{
Muchammad Fahmi Rizqi Abdillah¹, FX Ady Soesetijo², Dewi Kristiana² \\ ${ }^{1}$ Fakultas Kedokteran Gigi, Universitas Jember \\ ${ }^{2}$ Departemen Prostodonsia Fakultas Kedokteran Gigi Universitas Jember \\ Jl. Kalimantan 37, Jember. 68121. \\ Email:mfahmi_ra@yahoo.com
}

\begin{abstract}
The rough surface of a heat cured acrylic resin as a denture base can cause a pathogenic buildup of plaques and biofilms, so an effort to clean the denture base is needed. The available denture cleaning chemicals are proof of some disadvantages, so it is necessary to do research on alternative natural ingredients. Srikaya seed extract using ethanol $96 \%$ solvent has been shown to have antibacterial activity and with its various properties, so that it has the potential to become denture cleaning agents. Samples were made based on ADA No.17 specifications with 5 samples in each of the 6 treatment groups, sampling using Simple Random Sampling. Samples contaminated with S. mutans were soaked in srikaya seed extract $25 \%, 50 \%, 75 \%, 100 \%, 0.5 \% \mathrm{NaOCl}$ and sterile aquadest. There was a significant difference $(p$ $<0.05)$ in each treatment group. There is an influence of the difference in concentration of srikaya seed extract on the growth of $S$. mutans bacteria on a heat cured acrylic base.
\end{abstract}

Keywords: heat cured acrylic resin, S.mutans, srikaya seed extract, absorbance

\begin{abstract}
Abstrak
Permukaan kasar pada resin akrilik heat cured sebagai basis gigi tiruan dapat menyebabkan penumpukan plak dan biofilm yang bersifat patogenik, sehingga dibutuhkan usaha pembersihan basis gigi tiruan. Bahan kimia pembersih gigi tiruan yang tersedia buktinya memiliki beberapa kerugian, sehingga perlu dilakukan penelitian terhadap bahan alami alternatif. Ekstrak biji srikaya menggunakan pelarut etanol $96 \%$ terbukti memiliki aktivitas antibakteri serta dengan berbagai khasiatnya, sehingga berpotensi menjadi bahan pembersih gigi tiruan. Sampel dibuat berdasarkan spesifikasi ADA No.17 dengan jumlah 5 sampel pada tiap 6 kelompok perlakuan, pengambilan sampel menggunakan teknik Simple Random Sampling. Sampel yang telah dikontaminasi S.mutans direndam dalam ekstrak biji srikaya $25 \%, 50 \%, 75 \%, 100 \%, \mathrm{NaOCl}$ $0,5 \%$ dan aquadest steril. Terdapat perbadaan yang bermakna $(p<0,05)$ pada masing-masing kelompok perlakuan. Terdapat pengaruh perbedaan konsentrasi ekstrak biji srikaya terhadap pertumbuhan bakteri S. mutans pada basis akrilik heat cured.
\end{abstract}

Kata Kunci: resin akrilik heat cured, S.mutans, ekstrak biji srikaya, absorbansi 


\section{Pendahuluan}

Kehilangan gigi adalah kondisi lepasnya satu atau lebih gigi dari soketnya [1]. Berdasarkan data dari World Health Organization (WHO) pada tahun 2012 melapor- kan bahwa $30 \%$ populasi di dunia pada rentang usia $65-74$ tahun telah mengalami kehilangan seluruh gigi [2]. Kehilangan gigi dapat dilakukan perawatan melalui pemakaian gigi tiruan, hal ini memiliki beberapa tujuan yaitu mengembalikan fungsi fonetik, fungsi mastikasi, serta fungsi estetik [3].

Resin akrilik polimetil metakrilat heat cured merupakan bahan basis gigi tiruan yang sering digunakan karena memiliki beberapa kelebihan antara lain non-toksik, tidak mengiritasi, tidak mudah larut, estetik baik, mudah dimanipulasi dan direparasi, serta memiliki perubahan dimensi yang kecil [4]. Akan tetapi, resin akrilik yang bersifat polar dapat menyerap air, sehingga menyebabkan pecahnya molekul polimer dan menimbulkan keretakan mikro (micro cracking) pada basis gigi tiruan [5].

Kekasaran permukaan akrilik dapat mempengaruhi adesi mikroorganisme, hal ini dikarenakan adanya luas permukaan yang lebih besar serta tersedianya tempat berlindung untuk berkolonisasi [6]. Sebuah lapisan tipis yang dibentuk oleh saliva atau disebut pelikel merupakan mediator respons biologis yang dapat memicu perlekatan mikroorganisme, sehingga terbentuk plak pada basis akrilik. Plak yang terdiri dari kumpulan berbagai mikroorganisme (terutama bakteri) melekat pada permukaan gigi maupun basis akrilik melalui suatu polimer antara matriks bakteri dan komponen saliva [7].

Denture stomatitis adalah salah satu infeksi mukosa rongga mulut yang biasa disebabkan oleh jamur dan beberapa spesies bakteri pada jaringan yang tertutup oleh gigi tiruan [8]. Prevalensi denture stomatitis berkisar antara $30-50 \%$ pada pengguna gigi tiruan lengkap, dengan penderita biasa ditemukan pada lanjut usia dan lebih banyak ditemukan pada wanita [9]. Adhesi jamur maupun bakteri pada epitel rongga mulut merupakan tahap pertama dalam kolonisasi mikroba, dimana bakteri S.mutans merupakan inisiator pembentukan biofilm dan memfasilitasi adhesi mikroba ke mukosa maupun permukaan gigi tiruan [10]. S.mutans mensintesis sukrosa menjadi substrat polisakarida ekstraseluler berupa dekstran atau levan yang lengket, sehingga menyediakan media bagi jamur maupun bakteri lain untuk menempel pada basis gigi tiruan [11].

Pembersihan gigi tiruan penting dilakukan untuk menjaga kesehatan rongga mulut dan memperpanjang usia perawatan gigi tiruan [12] Larutan sodium hipoklorit ( $\mathrm{NaOCl}$ ) $0,5 \%$ adalah salah satu bahan kimia yang sering digunakan sebagai bahan pembersih gigi tiruan [13]. Akan tetapi $\mathrm{NaOCl}$ memiliki beberapa kerugian, antara lain korosif pada logam, memiliki bau dan rasa tidak enak, serta pada pembilasan yang kurang sempurna, residual yang tersisa dapat mengiritasi mukosa rongga mulut [14].

Produk alami telah banyak digunakan sebagai sumber bagi keperluan medis serta obatobatan. Hampir $61 \%$ obat-obatan yang dipasarkan di dunia mengandung senyawa yang merupakan produk alami [15]. Srikaya (Annona squamosa L.) adalah tanaman dalam keluarga Annonaceae yang mempunyai habitat umum di hutan tropis, serta dapat dibudidayakan di alam liar di berbagai bagian daerah yang beriklim tropis [16]. Karunia et al. (2017) dalam penelitiannya melaporkan bahwa pada ekstrak etanol biji srikaya menghasilkan zona hambat pada media biakan bakteri Escherichia coli dan Staphylococcus aureus. Uji kromatogram GC-MS (Gas Chromatography - Mass Spectrometer) pada ekstrak etanol biji srikaya telah mengidentifikasi adanya senyawa metil palmitat. Hexadecanoicacid methyl ester (metil palmitat) termasuk golongan asam lemak yang dapat merusak struktur dinding dan membran sel bakteri. Senyawa ini bekerja secara sinergis dengan berbagai senyawa aktif lainnya sehingga meningkatkan pengaruh aktivitas antibakteri pada ekstrak biji srikaya [17].

Berdasarkan uraian di atas dan penelitian terdahulu, menunjukkan bahwa ekstrak etanol biji srikaya mempunyai daya antibakteri dan berpotensi untuk dijadikan bahan alami alternatif pembersih gigi tiruan. Oleh karenanya penulis merasa perlu dilakukan penelitian mengenai pengaruh konsentrasi ekstrak biji srikaya (Annona squamosa L.) terhadap pertumbuhan bakteri S.mutans pada basis akrilik heat cured.

\section{Metode Penelitian}

Jenis penelitian yang digunakan adalah eksperimental laboratoris, dengan desain penelitian menggunakan true experiments jenis post test only control group design, yaitu hanya menggunakan post test atau tes akhir yang hasilnya akan dilakukan analisis untuk mengetahui keberhasilan penelitian. Penelitian dilakukan di Laboratorium Teknologi Kedokteran Gigi Fakultas Kedokteran Gigi Universitas Jember, Laboratorium Bio Science Fakultas Kedokteran Gigi Universitas Jember, 
Laboratorium Mikrobiologi Bagian Biomedik Fakultas Kedokteran Gigi Universitas Jember dan Laboratorium Botani dan Kultur Jaringan Jurusan Biologi Fakultas MIPA Universitas Jember. Waktu penelitian pada bulan Desember 2018 hingga Januari 2019.

\section{Sampel Resin Akrilik Heat Cured}

Sampel dibuat sesuai spesifikasi ADA No.17, dimana sampel berbentuk silindris dengan diameter $10 \mathrm{~mm}$ dan ketebalan sebesar $2 \mathrm{~mm}$ [18]. Adapun kriteria sampel lainnya adalah memiliki bentuk dan ukuran yang sama, tidak cacat/porus serta pemolesan hanya dilakukan pada 2 permukaan (salah satu permukaan alas dan permukaan tinggi/selimut silinder). Teknik pengambilan sampel menggunakan teknik simple random sampling. Populasi dibuat sejumlah 60 plat akrilik sesuai kriteria sampel. Jumlah sampel minimal yang dibutuhkan adalah 5 sampel untuk tiap kelompok perlakuan. Pengambilan sampel selanjutnya dilakukan secara simple random sampling, dimana peneliti mengambil sebanyak 30 sampel secara acak.

\section{Pembuatan Ekstrak Biji Srikaya}

Mengambil biji srikaya dari buah yang masak, kemudian mencuci bersih dan memasukkan biji ke dalam oven bahan, melakukan pengeringan dengan suhu oven $50^{\circ} \mathrm{C}$. Biji srikaya dihaluskan dan dilanjutkan proses maserasi menggunakan pelarut etanol 96\%. Perbandingan serbuk biji srikaya : pelarut $=1$ gram serbuk : $10 \mathrm{~mL}$ pelarut etanol $96 \%$. Proses maserasi dilakukan sebanyak 2 kali pengulangan. Selanjutnya maserat yang didapat diuapkan menggunakan rotator evaporator dengan suhu $70^{\circ} \mathrm{C}$ hingga didapatkan ekstrak kental biji srikaya [19].

\section{Metode Perendaman}

\begin{abstract}
Salah satu metode penggunaan pembersih gigi tiruan adalah dengan perendaman basis dalam cairan pembersih selama 6-8 jam selama waktu tidur di malam hari [20]. Dalam penelitian ini menggunakan waktu perendaman selama 6 jam sebagai waktu minimum seseorang melakukan perendaman gigi tiruan dalam sehari.
\end{abstract}

\section{Pengukuran Nilai Absorbansi S.mutans pada Plat Akrilik}

Sampel yang telah dilakukan perendaman sesuai kelompok perlakuan, selanjutnya dibilas menggunakan larutan PBS pH 7,0. Sampel dimasukkan kedalam media BHIB dan dilakukan vibrasi menggunakan vortex. Selanjutnya, pengukuran nilai absorbansi menggunakan spektrofotometer yang hasilnya dikonversikan dalam satuan $10^{8} \mathrm{CFU} / \mathrm{mL}$ berdasarkan rumus:

$$
\frac{(\text { abs. media }+ \text { S. mutans) - (abs.media) . X }}{\text { abs. larutan standar Mc. Farland 0,5 }}
$$

Keterangan :

$\mathrm{X}=$ konsentrasi bakteri dari larutan standar Mc. Farland 0,5 (3.10 $\mathrm{CFU} / \mathrm{mL})$

Nilai absorban media BHIB tanpa kuman $=0,04$ Nilai absorban larutan standar Mc. Farland 0,5 = 0,05

\section{Hasil}

Setelah melakukan pengukuran absorbansi S.mutans pada plat akrilik yang luruh menggunakan spektrofotometer, nilai yang didapat kemudian dikonversikan ke dalam satuan $10^{8} \mathrm{CFU} / \mathrm{mL}$ seperti dalam grafik berikut:

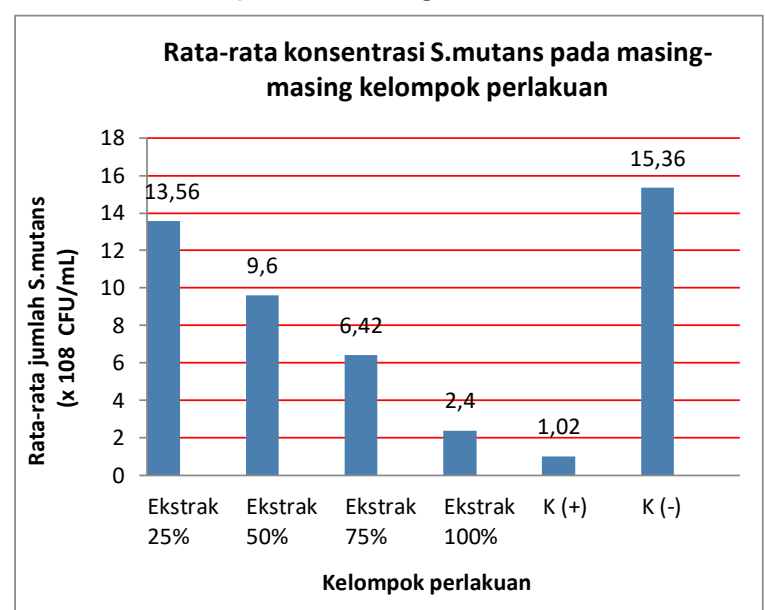

Gambar 4.1 Diagram batang rata-rata konsentrasi S. mutans (dalam $10^{8} \mathrm{CFU} / \mathrm{mL}$ ) pada pelat resin akrilik heat cured setelah direndam sesuai kelompok perlakuan selama 6 jam

\section{Pembahasan}

Basis gigi tiruan di dalam rongga mulut tidak berkontak langsung dengan mukosa, melainkan terdapat lapisan pelikel yang dapat menjadi mediator respon biologis sehingga memicu perlekatan mikroorganisme untuk membentuk plak [21]. S.mutans merupakan bakteri pada basis gigi tiruan yang membentuk koloni dan mensintesis sukrosa menjadi substrat polisakarida ekstraseluler seperti dekstran atau 
levan. Substrat tersebut besifat lengket dan merupakan sarana bagi jamur maupun bakteri lain untuk menempel pada basis gigi tiruan.

Sampel yang digunakan berupa plat resin akrilik heat-cured berbentuk silinder dengan diameter $10 \mathrm{~mm}$ dan tinggi $2 \mathrm{~mm}$. Plat resin akrilik dilakukan polishing pada 2 (dua) permukaan, yaitu pada salah satu permukaan alas dan permukaan tinggi silinder (plat) resin akrilik. Selain itu, berdasarkan American Dental Association (ADA) bahwa syarat basis gigi tiruan tidak boleh ada gelembung atau kekosongan (porus) bila dilihat tanpa pembesaran, maka sampel basis akrilik yang diambil pada penelitian ini merupakan sampel plat akrilik heat cured yang tidak porus [22].

Berdasarkan hasil penelitian, terdapat perbedaan pada hasil perendaman plat akrilik dalam berbagai kelompok konsentrasi. Hal ini menunjukkan bahwa terdapat pengaruh konsentrasi ekstrak biji srikaya terhadap nilai absorbansi bakteri S.mutans pada plat akrilik. Pada kelompok perlakuan perendaman plat resin akrilik heat cured dalam ekstrak biji srikaya, nilai absorbansi S.mutans paling kecil terdapat pada konsentrasi ekstrak $100 \%$, sedangkan nilai absorbansi S.mutans terbesar pada konsentrasi ekstrak 25\%.

Ekstrak biji srikaya mampu menghambat pertumbuhan S.mutans pada plat resin akrilik heat cured, hal ini dapat dilihat dari hasil penelitian berupa penurunan absorbansi S.mutans pada perendaman dalam berbagai konsentasi ektrak biji srikaya dibandingkan dengan perendaman menggunakan aquadest steril sebagai kontrol negatif. Hal ini ditunjang oleh penelitian yang telah dilakukan oleh Kulkarni C.P. (2017), yang mendapatkan hasil bahwa ekstrak etanol biji srikaya mempunyai daya antibakteri terhadap bakteri gram positif dan gram negative [23]. Ekstrak biji srikaya mampu menghambat pertumbuhan S.mutans karena memiliki beberapa kandungan senyawa fitokimia aktif yang ada di dalamnya seperti alkaloid, flavonoid, glikosida, tanin dan senyawa fenolik [24]. Selain itu, beberapa kandungan asam lemak berupa lebih dari satu jenis senyawa annonaceus acetogenins yang juga bersifat antibakteri [25].

Senyawa asetogenin (acetogenins) dengan kandungan terbesar dalam biji srikaya,yaitu squamosin dan squamostatin-A. Annonaceus acetogenins merupakan zat bioaktif pada tanaman golongan Annonaceae dan termasuk sebagai asetogenin dengan spektrum aksi yang Aluas, termasuk efek antibiotic [26]. Asetogenin bersifat antibakteri melalui beberapa proses mekanistik, antara lain, meningkatkan permeabilitas membran sehingga sel mengalami lisis, mengganggu rantai transfer elektron dan fosforilasi oksidatif serta menghambat enzim GTF (glycosyltransferase) pada membran yang berakibat pada terhambatnya pula aktivitas penyerapan nutrisi [27].

Senyawa fenolik berpengaruh terhadap membran sitoplasma sel bakteri. Akumulasi senyawa fenolik yang bersifaat hidrofobik dalam lipid bilayer dapat mengganggu interaksi lipidprotein dan meningkatkan permeabilitas membran. Hal tersebut menyebabkan terjadinya perubahan pada struktur membran dan terjadi kebocoran secara ekstensif pada komponen intraseluler. Hancurnya integritas membran dapat memfasilitasi masuknya lebih banyak agen lain yang bersifat antibakteri ke dalam sel [28].

Pada penelitian yang telah dilakukan oleh Mohamad et al. (2017), dalam mencari kandungan total saponin pada biji srikaya menggunakan pelarut etanol, mendapatkan hasil bahwa total saponin pada biji srikaya sebanyak $1,21 \%$ [29]. Saponin bereaksi pada gugus fosfat dalam fosfolipid membran sel dan kemudian dapat berpenetrasi ke dalam sel. Hal ini menyebabkan hilangnya permeabilitas serta denaturasi membrane sel, sehingga agen antibakteri lain dapat masuk ke dalam sel bakteri [30].

Kandungan flavonoid pada biji srikaya dapat bersifat antibakteri melalui proses denaturasi protein pada dinding sel bakteri dengan cara mengikat protein melalui ikatan hydrogen. Hal ini menyebabkan rusaknya membran sel sehingga terjadi kebocoran sitoplasma pada sel bakteri. Kandungan tannin menyebabkan gangguan permeabilitas sel berupa pembentukan polipeptida dinding sel yang kurang sempurna, sehingga sel-sel bakteri menjadi lisis oleh tekanan osmotik maupun tekanan fisik [31]. Kandungan senyawa alkaloid berupa anonaine merupakan senyawa yang umum ditemukan pada tanaman famili Annonaceae. Senyawa ini dapat menginduksi kerusakan DNA bakteri serta mengaktivasi caspase pada sel bakteri yang menyebabkan terjadinya apoptosis [32].

\section{Kesimpulan}

Perbedaan konsentrasi ekstrak biji srikaya (Annona squamosa L.) memberikan pengaruh yang berbeda dalam menghambat pertumbuhan $S$. mutans pada basis resin akrilik heat cured setelah proses perendaman. Semakin tinggi konsentrasi esktrak biji srikaya maka semakin baik dalam menghambat pertumbuhan bakteri 
S.mutans. Konsentrasi esktrak biji srikaya 100\% paling efektif menghambat pertumbuhan bakteri S.mutans pada kelompok perlakuan, sedangkan larutan $\mathrm{NaOCI} 0,5 \%$ memiliki daya hambat paling efektif dibanding semua kelompok perlakuan dan kelompok kontrol

\section{Daftar Pustaka}

[1] Anshary, Muhammad Fauzan, Cholil dan I W. Arya. 2014. Gambaran Pola Kehilangan Gigi Sebagian pada Masyarakat Desa Guntung Ujung Kabupaten Banjar. Jurnal Kedokteran Gigi Dentino 2(2): 139.

[2] Mokodompit, Rivon I., K. V. Siagian dan P. S. Anindita. 2015. Persepsi Pasien Pengguna Gigi Tiruan Lepasan Berbasis Akrilik yang Menggunakan Jasa Dokter Gigi di Kotamobagu. Jurnal e-GiGi 3(1): 216-222.

[3] Ambo, Andhika, A. Nurhapsari dan E. F. Rahman. 2015. Pengaruh Berbagai Konsentrasi Ekstrak Biji Adas (Foeniculum vulgare mill.) sebagai Denture Cleanser Terhadap Pertumbuhan Candida albicans pada Plat Akrilik. ODONTO Dental Journal 2(2): 62-67.

[4] Dharmautama, Moh., E. Machmud dan A. M. Maruapey. 2013. Pasta Pembersih Gigi Tiruan Bunga Rosella (Hibiscus sabdariffa L.) Menghambat Pembentukan Plak Pada Basis Akrilik Gigi Tiruan. Jurnal Dentofasial 12(1): 5-10

[5] Uzunoglu, E., A. Z. Y. Bicer, I. Dolapci dan A. Dogan. 2014. Biofilm-forming Ability and Adherence to Poly(methyl-methacrylate) Acrylic Resin Materials of Oral Candida albicans Strains Isolated from HIV Positive Subjects. The Journal of Advanced Prosthodontics 6: 30-34.

[6] Morgan, T.D. dan M. Wilson. 2001. The Effects of Surface Roughness and Type of Denture Acrylic on Biofilm Formation by Streptococcus oralis in a Constant Depth Film Fermentor. Journal of Applied Microbiology 91: 47-53.

[7] Atmaja, Widyapramana Dwi. 2015. Kulit Buah Kakao (Theobroma kakao L.) sebagai Bahan Pembersih Gigi Tiruan dan Mencegah Perlekatan Candida albicanss pada Basis Plat Akrilik. Stomatognatic (J. K. G Unej) 12(2): 46-50.

[8] Prabha.J, Lakshmi. 2015. Bacterial Load in Denture Stomatitis. Journal of Pharmaceutical Science and Research
7(7): 453-454.

[9] Herawati, Erna dan Dwi Novani. 2017. Penatalaksanaan Kasus Denture Stomatitis. Jurnal Kedokteran Gigi Unpad 29(3): 179-183.

[10] Vasconcelos, Laurylene César de S., F. C. Sampaio, M. C. C. Sampaio, M. d. S. V. Pereira, M. H. P. Peixoto. 2010. Streptococcus mutans in Denture Stomatitis Patients Under Antifungal Therapy. Rev. odonto ciênc., 25(21): 120125

[11] Silvia, Sheila, A. A. Djais dan S. A. Soekanto. 2018. The Amount of Streptococcus mutans Biofilm on Metal, Acrylic Resin, and Valplast Denture Bases. Journal of International Dental and Medical Research 11(3): 899-905.

[12] Zulkarnain, M. dan Jefferson Daniel B. 2014. Pengaruh Perendaman Basis Gigi Tiruan Resin Akrilik Polimerisasi Panas dalam Larutan Sodium Hipoklorit dan Vinegar Cuka Putih Terhadap Kekasaran Permukaan dan Stabilitas Warna. Jurnal Material Kedokteran Gigi 3(1): 22-32

[13] Porwal, Anand, M. Khandelwal, V. Punia dan V. Sharma. 2019. Effect of Denture Cleansers on Color Stability, Surface Roughness, and Hardness of Different Denture Base Resins. The Journal of Indian Prosthodontic Society 17(1): 1-7

[14] Watcharapichat, Pijitra, C. Kunavisarut, P. Pittayachawan, T. Tengrangsan. 2014. The Effect of Denture Cleansing Solutions on the Retention of Pink Locator ${ }^{\circledR}$ Attachment: 1 Year Simulation. Mahidol Dental Journal 34(3): 204-214.

[15] Aamir, Javed, A. Kumari, M. N. Khan dan S. K. Medam. 2013. Evaluation of the Combinational Antimicrobial Effect of Annona squamosa and Phoenix dactylifera Seeds Methanolic Extract on Standard Microbial Strains. International Research Journal of Biological Sciences 2(5): 68-73.

[16] Mwihia, Stephen K., M. P. Ngugi, J. M. Maingi, J. k. Kamau, A. W. Muhuha. 2017. Screening of Phytochemicals and Antibacterial Activity of Seed Extracts of Kenyan Sugar Apple (Annona squamosa). International Journal of Life Sciences Research 5(3): 46-52.

[17] Karunia, Sabrina Dwie, Supartono dan W. Sumarni. 2017. Analisis Sifat Antibakteri Ekstrak Biji Srikaya (Annona squamosa L.) dengan Pelarut Organik. Indonesian 
Journal of Chemical Science 6(1): 56-50.

[18] Al-Muthaffer, Azad M.R. dan Shatha S. AlAmeer. 2012. Effect of Thermocycling on Some Mechanical Properties of Polyamide Hypoallergenic Denture Base Material (Comparative Study). J Bagh College Dentistry 24(2).

[19] Rianto, Leonov, I. A. Handayani dan A. Septiyani. 2015. Uji Aktivitas Ekstrak Etanol 96\% Biji Srikaya (Annona squamosa L.) sebagai Antidiare yang Disebabkan oleh Bakteri Shigella dysenteriae dengan Metode Difusi Cakram Jurnal IImiah Manuntung 1(2): 181-186.

[20] Naini, Amiyatun. 2012. Perbedaan Stabilitas Warna Bahan Basis Gigi Tiruan Resin Akrilik dengan Resin Nilon Termoplastis terhadap Penyerapan Cairan. Stomatognatic (J.K.G Unej) 9(1): 28-32.

[21] Atmaja, Widyapramana Dwi. 2015. Kulit Buah Kakao (Theobroma kakao L.) sebagai Bahan Pembersih Gigi Tiruan dan Mencegah Perlekatan Candida albicanss pada Basis Plat Akrilik. Stomatognatic (J. K. G Unej) 12(2): 46-50.

[22] Vitalariu, Anca Mihaela, D. Diaconu, D. Tatarciuc , O. Aungurencei, M. Moisei dan L. Barlean. 2015. Effects of Surface Characteristics of the Acrylic Resins on the Bacterial Colonization. Revista de Chimie Bucharest - Original Edition 66(10): 17201724.

[23] Kulkarni C.P. 2017. Antibacterial and Insecticidal Activity of Crude Seed Extracts of Annona squamosa L.International Journal of Pharmaceutical Science Invention (IJPSI) 6(9): 25-29.

[24] Aher, P. S., Y.S. Shinde dan P. P.Chavan. 2012. In Vitro Evaluation of Antibacterial Potential of Annona Squamosa L. Against Pathogenic Bacteria. International Journal of Pharmaceutical Science and Research (IJSPR) 3(5): 1457-1460.

[25] Ristiati N. P., N. L. P. M. Widiyanti, S. Mulyadiharja dan I P. A. Putra. 2018. Effectivity of Custard Apple's (Annona squamosa) Seed Extract in Various Concentrations on the Growth of Escherichia coli. Journal of Physics: Conference Series 1116(2018).

[26] Leatemia , J. Audrey dan Murray B. Isman. 2004. Toxicity and Antifeedant Activity of Crude Seed Extracts of Annona squamosa (Annonaceae) Against Lepidopteran Pests and Natural Enemies. International Journal of Tropical Insect Science 24(2): 150-158.

[27] Yoon, Bo Kyeong, J. A. Jackman, E. R. V. González dan N. J. Cho. 2018. Antibacterial Free Fatty Acids and Monoglycerides: Biological Activities, Experimental Testing, and Therapeutic Applications. International Journal of Molecular Sciences 19(4): 1-40.

[28] Wu, Yanping, J. Bai, K. Zhong, Y. Huang, Hu. Qi, Y. Jiang dan H. Gao. 2016. Antibacterial Activity and MembraneDisruptive Mechanism of 3-p-transCoumaroyl-2-hydroxyquinic Acid, a Novel Phenolic Compound from Pine Needles of Cedrus deodara, against Staphylococcus aureus. Molecular Diversity Preservation International (MDPI): Molecules Journal 21(1084): 1-12.

[29] Mohamad, Nasser, E. M. Majid, A. S. Falah, C. Layla, H. Akram, C. Ali dan R. Hassan. 2017. Antibacterial, Antioxidant and Antiproliferative Activities of the Hydroalcoholic Extract of the Lebanese Annona squamosa L. Seeds. International Research Journal of Pharmacy 8(1): 1-7.

[30] Berniyanti, Titiek dan Erma Mahmiyah. 2015. Microbiological Studies on the Production of Antimicrobial Agent by Saponin Aloe vera Linn Against Streptococcus sanguinis. Research Journal of Microbiology 10(8): 385-392.

[31] Ristiati N. P., N. L. P. M. Widiyanti, S. Mulyadiharja dan I P. A. Putra. 2018. Effectivity of Custard Apple's (Annona squamosa) Seed Extract in Various Concentrations on the Growth of Escherichia coli. Journal of Physics: Conference Series 1116 (2018).

[32] Pinto, Nicolas C.C., J. B. Silva, L. M. Menegati, M. C. M. R. Guedes, L. B. Marques, T. P. D. Silva, R. C. N. D. Melo, E. M. D. Souza-Fagundes, M. J. Salvador, E. Scio dan R. L. Fabri. 2017. Cytotoxicity and Bacterial Membrane Destabilization Induced by Annona squamosa L. Extracts. Annals of the Brazilian Academy of Sciences 89(3): 2053-2073. 